\title{
Chemotherapy-induced transverse melanonychia
}

\author{
Chen Fei $\mathrm{Ng}$ 지 , Hui Jan Tan, Rabani Remli
}

Department of Medicine, Universiti Kebangsaan Malaysia Medical Centre, Cheras, Kuala Lumpur, Malaysia

\section{Correspondence to Dr Chen Fei Ng; n.chenfei@gmail.com}

Accepted 10 August 2021
Check for updates

(C) BMJ Publishing Group Limited 2021. No commercial re-use. See rights and permissions. Published by BMJ.

\begin{tabular}{l}
\hline To cite: Ng CF, Tan HJ, \\
Remli R. BMJ Case Rep \\
2021;14:e245878. \\
doi:10.1136/bcr-2021- \\
245878 \\
\hline
\end{tabular}

\section{DESCRIPTION}

A 40-year-old man presented with painless swelling of the neck for 3 years. He was well until 3 months prior to the presentation when he started losing weight and feeling lethargic. Clinical examination showed an enlarged left cervical lymph node measuring about $4 \times 4 \mathrm{~cm}$. Lymph node biopsy revealed scattered mononuclear Hodgkin-like cells and binucleated Reed-Sternberg cells with CD30 positivity in keeping with classical Hodgkin lymphoma. Staging Positron emission tomography (PET)-CT scan showed multiple hypermetabolic supradiaphragmatic nodes. Bone marrow aspiration and trephine biopsy were unremarkable. He was then commenced on ABVD chemotherapy (doxorubicin, bleomycin, vinblastine and dacarbazine). Reassessment after three cycles of chemotherapy showed significant clinical and radiological improvement. However, he reported hyperpigmentation of all the nails which had developed 2 months after the commencement of chemotherapy (figure 1). There was no mucosal pigmentation or skin lesion elsewhere. He denied taking any medication or supplement. He was diagnosed with chemotherapy-induced transverse melanonychia.

Melanonychia is a result of increased melanin deposition in the growing nail beds. Transverse, longitudinal and diffuse form of melanonychia have been described. ${ }^{1}$ The mechanism of melanonychia can be due to melanocytic activation or melanocytic hyperplasia. Melanonychia affecting multiple nails can be physiological, occurring as a normal variant in skin of colour and during pregnancy. It can be seen in association with certain syndromes and can also occur secondary to local trauma, chronic nail infection, inflammatory skin disease, endocrine disorders, nutritional deficiency, systemic disease, medications, phototherapy and X-ray exposure. Transverse melanonychia is uncommon and frequently observed in association with medications. Chemotherapeutic agents including doxorubicin, bleomycin and dacarbazine have all been recognised to cause transverse melanonychia. ${ }^{2}$ The intermittent cycles of chemotherapy exert direct toxic effects on nail matrix causing melanocytic activation, which leads to the development of transverse melanonychia. It typically resolves after the completion of chemotherapy and warrants no treatment. Interestingly, the occurrence of this clinical sign is not frequently seen in patients receiving

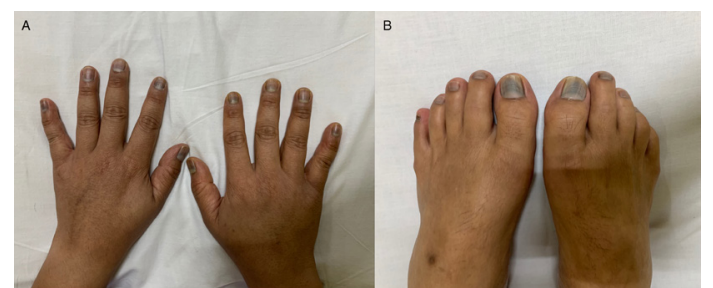

Figure 1 There were transverse pigmented bands of bluish-brown hue in varying degree of intensity involving all the finger nails (A) and toe nails (B), with sparing of the lunula.

chemotherapeutic agents. The sparing of the lunula in transverse melanonychia is also rarely described. Hence, the recognition of this benign nail condition is essential to avoid unnecessary investigation or treatment.

\section{Learning points}

- Melanonychia refers to hyperpigmentation of the nails as a result of increased melanin deposition.

- The condition may be caused by certain chemotherapeutic agents such as doxorubicin, bleomycin and dacarbazine.

- Chemotherapy-induced transverse melanonychia is a benign condition and it typically resolves after the completion of chemotherapy.

Contributors CFN: Conception and design, acquisition of data or analysis and interpretation of data; drafting and revising the article. HJT and RR: Analysis and interpretation of data; revising the article.

Funding The authors have not declared a specific grant for this research from any funding agency in the public, commercial or not-for-profit sectors.

Competing interests None declared.

Patient consent for publication Obtained.

Provenance and peer review Not commissioned; externally peer reviewed.

\section{ORCID iD}

Chen Fei Ng http://orcid.org/0000-0003-2540-9905

\section{REFERENCES}

1 Hinds G, Thomas VD. Malignancy and cancer treatment-related hair and nail changes. Dermato/ Clin 2008;26:59-68.

2 Jefferson J, Rich P. Melanonychia. Dermatol Res Pract 2012;2012:1-8 
Copyright 2021 BMJ Publishing Group. All rights reserved. For permission to reuse any of this content visit https://www.bmj.com/company/products-services/rights-and-licensing/permissions/

BMJ Case Report Fellows may re-use this article for personal use and teaching without any further permission.

Become a Fellow of BMJ Case Reports today and you can:

- Submit as many cases as you like

- Enjoy fast sympathetic peer review and rapid publication of accepted articles

Access all the published articles

Re-use any of the published material for personal use and teaching without further permission

Customer Service

If you have any further queries about your subscription, please contact our customer services team on +44 (0) 2071111105 or via email at support@bmj.com.

Visit casereports.bmj.com for more articles like this and to become a Fellow 